\title{
Download $\mathrm{Q}$
}

https://doi.org/10.17721/2308-135 $\underline{X} . \underline{.2019 .43 .147-162}$

UDC 330.34:[338.481:330.322]:332.146(477.75)

Masiuk Yuliia Olehivna, PhD in Economics, Ivan Franko National University of Lviv, Lviv, Ukraine, e-mail: joliebox@gmail.com

ANALYSIS OF SOCIO-ECONOMIC DEVELOPMENT AND ORGANIZATION OF TOURISM ACTIVITY ON THE TERRITORY OF THE ANNEXED PENINSULA OF THE AUTONOMOUS REPUBLIC OF CRIMEA: PROBLEMS, MEASURES, CONSEQUENCES

Purpose. In article they are analysed socio economic development on the territory of annexed peninsula of Autonomous Republic of Crimea, the main propulsion of economy of the peninsula in postSoviet period in the times of independence of Ukraine characterized, as well as feature of functioning of various branches of economy after 2014

A nnexation development of tourist branch and the role of tourism in the peninsula economy in the period of independence of Ukraine and after occupation is analysed. 
Methods. Use of the principle of system approach in given work confirms necessity of complex research of big and difficult objects of tourist infrastructure together with the infrastructure of other branches of economy, studying of them as uniform functioning of all elements and parts whole with co-ordination.

Results. The role of tourism is determined as pre-emptive branch of the economy of the region in 2000s the tendencies of development of business, industry and accompanying branches of the economy in postSoviet period are analysed.

It is proven of the reason of the reduction of tourist flows as a result of annexation of the peninsula, militarization and problems with transport infrastructure.

Scientific novelty. Scientific novelty of research is in absence of urgent information about conditions, the reasons of socioeconomic development of the territory of Autonomous Republic of Crimea in historical and economical aspects.

Practical importance. Main provisions and conclusions stated in given article, can be used in scientific researches connected with further development of strategic guiding lines for development of the region economy; at preparation of educational and methodical allowances, as well as disciplines; Conducted researches can become arguments at perfecting of the legislation directed to adjustment of tourist activity in the region, country.

Key words: socio-economic development, economy, tourism, tourism activity, investments, transport infrastructure.

\section{References:}

1.Main Department of Statistics in the Autonomous Republic of Crimea. - Access mode: [ http: //www.sf.ukrstat.gov.ua/index.htm ].

2.

Butchenko

M. Leaf bridge //

Maxim Butchenko; [Under. ed. Kravchuk N., Pavlenko A. et al.]. - Ukrainian weekly political magazine «New time». - K: Publishing House «Media-DK». - 2018. - № 28. 
3.Vikhrov M. Peninsula of officials and soldiers // Maxim Vikhrov; [Under. ed. D. Krapivenko et al.]. - Ukrainian Week LLC. - M.: «NEW PRINTING». - 2018. - № 32 (560). - Access mode: [ http://tyzhden.ua/Economics/217995 ].

4.Vorozhbit A. Western companies in the Crimea are cunning and even more cunning // Olga Vorozhbit; [Under. ed. D. Krapivenko et al.]. - Ukrainian Week LLC. - M.: «NEW PRINTING». 2018. - № 32 (560). - Access mode: [

http://tyzhden.ua/Economics/218003 ].

5.Zvarych E. Treacherous rest // Elena Zvarych; [Under. ed. E. Gordeychik et al.]. - Focus Weekly, FOCUS MEDIA LLC. - M .: Novy Druk LLC. - 2018. - №32 (587). - pp. 20-22.

6.Klimenko A. Return of the Soviet Crimea // Andrey Klimenko, Tatiana Guchakova; [Under. ed. D. Krapivenko et al.]. - Ukrainian Week LLC. - M.: «NEW PRINTING». - 2018. - № 32 (560). Access mode: [ http://tyzhden.ua/Economics/218017 ].

7.JSC «Krymtur» .- Access mode: [ https://www.krymtur.com/ ].

8.Group of travel companies «Kandahar».- Access mode:[ http://www.kandagar.net/infocat/o-kompanii/ ].

9.Company «Dnepr-sea». - Access mode: [ http://dnepr-more.com/ ].

10.«Elen-Travel Company»- Access Mode: [

https://elentravel.com.ua/?gclid=CjwKCAjCww5TbBRAIEiwAYQf_E46Kmyqn7TkA4uPKCmhvue5DwgJaGf 9EQC_47ecFBptdgXyiLV98CCCCCAC

11.Travel agency «ASTRA».- Access mode: [ http://astra-tour.com/ ].

Travel Agency «Planet Travel». - Access mode: [ http://hot-tour.mk.ua/ Planet of Travel]. 